\title{
Recent Advances in Application of Male Germ Cell Transplantation in Farm Animals
}

\author{
Ali Honaramooz and Yanfei Yang \\ Department of Veterinary Biomedical Sciences, Western College of Veterinary Medicine, University of Saskatchewan, 52 Campus Drive, \\ Saskatoon, Saskatchewan, Canada S7N 5B4 \\ Correspondence should be addressed to Ali Honaramooz, ali.honaramooz@usask.ca
}

Received 11 May 2010; Revised 25 August 2010; Accepted 1 September 2010

Academic Editor: Stefan Schlatt

Copyright ( $\odot 2011$ A. Honaramooz and Y. Yang. This is an open access article distributed under the Creative Commons Attribution License, which permits unrestricted use, distribution, and reproduction in any medium, provided the original work is properly cited.

Transplantation of isolated germ cells from a fertile donor male into the seminiferous tubules of infertile recipients can result in donor-derived sperm production. Therefore, this system represents a major development in the study of spermatogenesis and a unique functional assay to determine the developmental potential and relative abundance of spermatogonial stem cells in a given population of testis cells. The application of this method in farm animals has been the subject of an increasing number of studies, mostly because of its potential as an alternative strategy in producing transgenic livestock with higher efficiency and less time and capital requirement than the current methods. This paper highlights the salient recent research on germ cell transplantation in farm animals. The emphasis is placed on the current status of the technique and examination of ways to increase its efficiency through improved preparation of the recipient animals as well as isolation, purification, preservation, and transgenesis of the donor germ cells.

\section{Development of Male Germ Cell Transplantation Technique in Rodents}

Germ cell transplantation (GCT), also referred to as spermatogonial stem cell (SSC) transplantation, is a powerful technology first introduced in 1994 by Brinster and colleagues. Although initially developed using a mouse model, GCT has important applications in the study and manipulation of spermatogenesis in many species. In this method, testis cells obtained from a fertile donor male are transferred into the seminiferous tubules of infertile recipient testes where donor-derived sperm production can occur, allowing the recipient to sire progeny $[1,2]$ (Figure 1). In essence, donor SSCs deposited in the lumen of the recipient seminiferous tubules are allowed by the Sertoli cells to migrate to the basolateral compartment of the tubule, to proliferate, form new colonies and initiate donor-derived spermatogenesis $[3,4]$. Following the original introduction of GCT in mice $[1,2]$, the technique was also successful among rats $[5,6]$. In laboratory rodents, GCT not only provides a unique opportunity for gaining new insight into spermatogenesis and the biology of the stem cell niche, but also presents a unique functional bioassay to test the competence of putative SSCs. Furthermore, GCT also offers a new strategy for preservation of male fertility and an alternative approach for generation of transgenic animals $[7,8]$.

\section{Cross-Species Application of Male Germ Cell Transplantation}

Rather surprisingly, cross-species (xenogeneic/heterologous) transplantation of testis cells from donor rats into recipient mice resulted in complete rat spermatogenesis [9]. This development sparked an interest in the idea of using the laboratory mouse as a universal recipient model for testis cells from different donor species. However, while hamster testis cells transferred into recipient mouse testes also developed complete donor-derived spermatogenesis [10], GCT from genetically more distant donor species, including farm animals, into mice only resulted in colonization or 
proliferation of SSCs but not in complete spermatogenesis [11-15] (Table 1). This block in differentiation of donor germ cells is believed to be due to the incompatibility of donor germ cells and mouse Sertoli cells [16]. Although GCT from nonrodent species into the mouse testis did not result in complete spermatogenesis, it still is the only available bioassay for detecting the colonization potential of SSCs in a given population of donor testis cells from any species [11, $13,17]$. Interestingly, when (rather than transferring isolated testis cells into the seminiferous tubules) small fragments of testis tissue were transplanted under the back skin of recipient mice, complete donor-derived spermatogenesis was observed from a wide range of donor species, including farm animal species [18-26].

\section{Cell Transfer Techniques}

The original procedures described for the transfer of donor male germ cells into the seminiferous tubules of recipient mice could not be directly applied in farm animals. Therefore, we used ultrasound-guided cannulation of the centrally located rete testis [41] to infuse donor germ cells by gravity flow which was successful in vivo for pigs and goats $[32,33]$. The procedure could be completed in 15$30 \mathrm{~min}$ and resulted in filling of about half of the recipient seminiferous tubules with donor cells. This methodology has been successfully adapted for use in rams and bulls in vivo $[36,40,42]$. Injection into the extratesticular rete testis using ultrasound guidance or surgical dissection was also reported to be applicable for use in rams $[39,43]$. The success of the rete testis injection approach was further shown through donor-derived sperm production by the recipients $[34,44]$ and birth of progeny carrying the donor characteristics [34, 40].

\section{Preparation of Recipient Animals}

The success of GCT between unrelated laboratory rodents appears to depend on the availability of recipients of strain that are genetically compatible with the donor animals, are inherently immunodeficient, or have undergone immunosuppressive treatments [1, 45, 46]. Surprisingly, however, recipient pigs, goats, sheep, and bulls with fully functional immune systems did not reject germ cells from unrelated donors, making the practical application of the approach more feasible in farm animals [32-34, 39, 40].

Studies show that donor-derived spermatogenesis could be significantly improved when the recipient's endogenous germ cells are suppressed or depleted $[6,47]$. Unlike in laboratory rodents, mutant animals with genetically impaired spermatogenesis are not readily available for use in work with farm animals. The azoospermic Klinefelter bull used in a study was determined not to be a useful recipient model for GCT [42], while limited donor-derived spermatogenesis was observed after GCT into two boars affected by the immotile short-tail sperm defect [37].

An alternative to the use of recipient animal models with congenital germ cell deficiency is removal of endogenous germ cells by cytoablative methods to facilitate further access to, and the availability of, the stem cell niche. We and others have achieved partial ablation of endogenous germ cells using busulfan (a chemotherapy agent) treatment of postnatal pigs $[37,48]$ and also during the in utero development of piglets [48]. This latter approach is particularly useful for preparation of piglets because treating a pregnant sow will result in producing multiple potential recipients at higher efficiency, but without the harmful health effects observed after treating postnatal piglets [48]. Where the facilities are available, local irradiation of testes can also be very effective in reducing the number of endogenous germ cells in recipient goats, rams and bulls $[36,48,49]$.

For practical reasons, most researchers have used immature recipients for GCT in farm animals, while recipients for GCT in laboratory rodents are typically adults. The use of immature recipient testis not only facilitates access of the transplanted donor germ cells to the tubular basolateral compartment (because it lacks the hindering multiple layers of germ cells), it also provides a more favorable environment than adult testes for engraftment and expansion of donor germ cells [50]. In our previous studies, we used immature pig and goat recipients with no pretreatment [32-34], resulting in $\sim 7 \%$ donor-derived progeny in goats [34], while after preparation of immature recipients with testis irradiation, the progeny rate averaged $\sim 8 \%$ or $10 \%$ in sheep and goats, respectively, $[27,40]$. These results may indicate that while gradual progress in the efficiency of GCT in farm animals is being achieved, recipient preparation of immature recipients may not be as critical as that for adult recipients $[6,50]$. It may also be concluded that recipient preparation is only part of the requirements for a successful GCT, and that other aspects of the system also need to be optimized before a higher efficiency is expected.

\section{Preparation of the Donor Germ Cells}

The efficiency of GCT is also highly dependent on the relative abundance of SSCs transplanted [3, 51-53]. In the adult testis, SSCs are a rare population, making up only $\sim 0.02 \%$ to $0.2 \%$ of testis cells in mice and rats [54-56]. The efficiency of colony establishment is also low, and only $1 \%$ [53] or $7-20 \%$ of the transplanted SSCs will actually colonize the recipient testis $[3,52,53]$. Naturally, increasing the number of SSCs in the donor population of cells prior to GCT will have a direct effect on the number of expected spermatogenic colonies in recipients $[51,52,57]$.

5.1. Choice of Donors. For GCT in rodents, several strategies including the use of cryptorchid, vitamin-A deficient or Steel (Sl) mutant mice can be used to increase the proportion of nondifferentiated spermatogonia in the population of donor cells [58-61]. Surgical induction of cryptorchidism in the donor, 2-3 months prior to use in GCT, is a common strategy resulting in elimination of a large number of differentiated germ cells, and thereby up to 23-fold increase in the relative number of SSCs [51]. These strategies have not been well pursued for use in farm animal GCT, partly 
TABLE 1: Summary of germ cell transplantation in different donor and recipient species.

\begin{tabular}{|c|c|c|c|c|c|c|}
\hline \multirow[b]{2}{*}{ Donor } & \multirow[b]{2}{*}{ Recipient } & \multicolumn{5}{|c|}{ Donor-derived } \\
\hline & & Colonization of SSCs & Spermatocytes & Spermatozoa & Offspring & Transgenic progeny \\
\hline Mouse & Mouse & + & + & $+[2]$ & + & $+[1,27,28]$ \\
\hline Rat & Rat & + & + & + & + & $+[29,30]$ \\
\hline Rat & Mouse & + & + & $+[9,31]$ & - & - \\
\hline Hamster & Mouse & + & + & $+[10]$ & - & - \\
\hline Rabbit & Mouse & + & {$[11]$} & - & - & - \\
\hline Dog & Mouse & + & {$[11]$} & - & - & - \\
\hline Pig & Mouse & + & {$[13]$} & - & - & - \\
\hline Cattle & Mouse & + & {$[13]$} & - & - & - \\
\hline Horse & Mouse & + & {$[13]$} & - & - & - \\
\hline Baboon & Mouse & + & {$[14]$} & - & - & - \\
\hline Mouse & Pig & $-[32]$ & - & - & - & - \\
\hline Goat & Goat & $+[33]$ & + & + & + & $+[34]$ \\
\hline Cattle & Cattle & $+[35]$ & + & $+[36]$ & - & - \\
\hline Cat & Mouse & + & {$[12]$} & - & - & - \\
\hline Pig & Pig & $+[32]$ & + & $+[37]$ & - & - \\
\hline Dog & Dog & + & + & $+[38]$ & - & - \\
\hline Sheep & Sheep & + & + & $+[39,40]$ & $+[40]$ & - \\
\hline
\end{tabular}

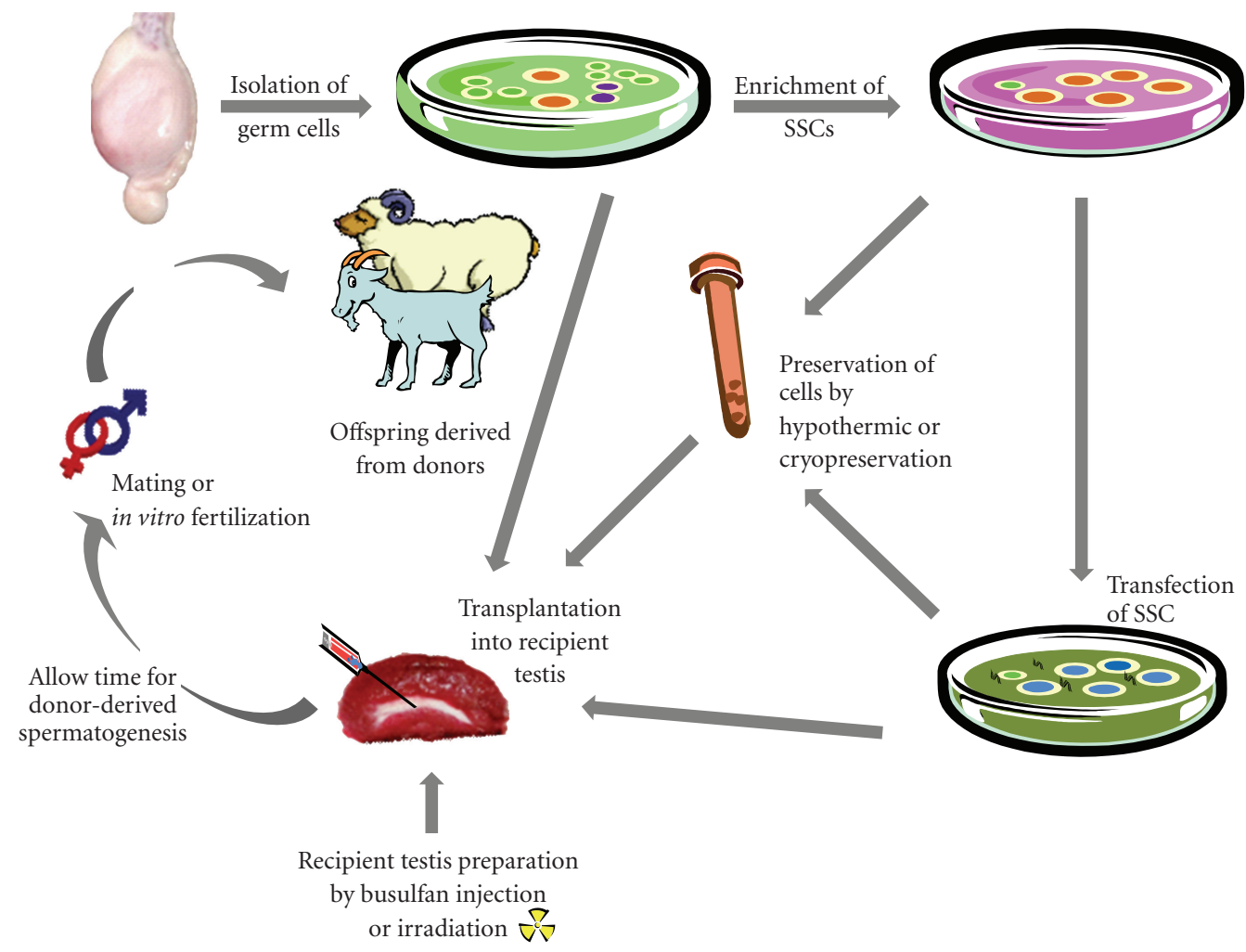

FIgURE 1: A schematic representation of procedures involved in germ cell transplantation in farm animals. A single-cell suspension of germ cells is prepared after enzymatic digestion of the donor testis for transplantation into recipient testes. Alternatively, the number of spermatogonial stem cells (SSCs) can be enriched in the donor cells and the resultant cells can be used fresh or preserved (for short term through hypothermic preservation or long-term by cryopreservation) and/or transfected with genes of interest before transplantation. The recipient animal can be treated with busulfan or undergo local irradiation of the testes to reduce the number of endogenous SSCs, in preparation for germ cell transplantation. Transplanted SSCs can form colonies of donor-derived spermatogenesis and produce sperm to allow the recipient to sire progeny carrying the donor haplotype. 
to avoid the added complication of the procedure. On the other hand, testes from immature donors have been a frequent source of cells for use in farm animal GCT, because they provide a population of cells with a naturally higher proportion of germline stem cells than those of adults. In the neonatal testis, gonocytes are the only type of germ cells present, comprising $1-2 \%$ of total number of isolated testis cells in rodents $[62,63]$ or $\sim 7 \%$ of intratubular cells in piglets [48]. Gonocytes have germline stem cell potential and upon transplantation into recipient testes are able to establish complete spermatogenesis [62]. Therefore, the neonatal/immature testis provides a logical source for GCT, especially for farm animals.

5.2. Isolation of Donor Germ Cells. Procedures for isolation of testis cells vary among laboratories, depending on the target cell types and the donor species. Two-step enzymatic digestion has been widely applied to isolate both gonocytes and SSCs in many species. In the first digestion step, collagenase and hyaluronidase enzymes are usually used to largely remove testis interstitial cells. As a second step, trypsinEDTA (with or without additional enzymes) is used to break down seminiferous cords/tubules, while DNase is added to prevent cellular aggregation [64]. Using two-step digestion usually results in a maximum of $10 \%$ gonocytes/SSCs in the freshly isolated testis cells $[62,63,65-70]$. As outlined above, the proportion of SSCs can be increased using physically or genetically modified donors [58-61].

After a systematic evaluation of several potential factors affecting germ cell isolation, we recently developed a novel three-step strategy (combining vortexing and digestion) to isolate porcine testis cells with a gonocyte proportion of $\sim 40 \%$, (among fresh cells and before applying enrichment methods) [71] as compared with the conventional twostep enzymatic digestion resulting in collection of $\sim 7 \%$ gonocytes.

5.3. Enrichment/Purification of Donor Germ Cells. Depending on the donor cells, diverse strategies can be used to enrich (but rarely purify) SSCs [72]. These strategies are generally based on fluorophore-labeled antibody separation of testis cells using fluorescent activated cell sorting (FACS) [51, $65,68,73-75]$, magnetic activated cell separation (MACS) $[57,65,75-78]$, forward/side scatter measurements in FACS $[51,68,79]$, density gradient centrifugation $[43,65,67,74$, $80,81]$, or differential plating $[43,65,67,74,81]$. Using these approaches, SSCs have been enriched to as high as $75 \%$ in the population of donor testis cells from farm animals [43, 65, 67, 74]. However, work on enrichment of gonocytes, as opposed to SSCs, has been limited to a few reports in rodents and pigs $[69,82-84]$. We recently assessed the efficiency of porcine gonocyte enrichment using density gradient and differential plating strategies. We found that gonocytes can be enriched to more than $80 \%$ using either Nycodenz density gradient or differential plating (with fibronectin and poly-D-lysine coatings), and to a purity of more than $90 \%$ by combining the two strategies (Yang and Honaramooz, unpublished data).
5.4. Preservation of Donor Testis Tissue and Cells. Different from the situation for GCT in rodents, preparation of the required high numbers of germ cells from testes of donor farm animals for same day transplantation could be a timemanagement challenge. Aside from the time needed for collection of donor testes from farm animals, the high volume of the tissue and presence of dense connective tissue make the process of digestion time consuming and often requiring the tissue or cells to be stored overnight before GCT [32, 39, 40, 43, 74]. If the time required for enrichment of germ cells followed by their transgenesis is added, the preparation time could be longer, and the need for preservation of the tissue/cells is even greater.

Cryopreservation of isolated germ cells allows their storage for extended periods of time; however, not only is it not suitable for short-term preservation, it can also damage cells, as cryopreservation of bovine germ cells resulted in cell survival rates of $\sim 50-70 \%$ [85]. We also showed the feasibility of cryopreserving fragments of porcine testis tissue $[86,87]$ resulting in a postdigestion cell survival of $\sim 55-88 \%$ while maintaining the in vivo developmental potential [86].

Short-term preservation of testis cells and tissue, on the other hand, is necessary and could be more suitable for immediate applications such as in GCT and for shipment of cells/tissue between collaborating laboratories. Hypothermic temperatures (above freezing point but below the body temperature) cause a decrease in cellular metabolism rate, oxygen demand, and energy consumption and therefore prolong cell viability. Ice-cold storage of testis tissue for 1 or 2 days was suggested to improve donor-derived spermatogenesis after xenografting $[87,88]$. Testis tissue stored at refrigeration temperature for 3 days maintained its structural integrity [89], but cell viability starts to decrease [87]. We recently showed that using proper media, isolated cells from donor piglets could be maintained even at room temperature for at least 24 hours and up to 6 days at refrigeration temperature, resulting in up to $88 \%$ afterstorage cell viability, and without changing the germ cell proportions or cell culture properties $[89,90]$.

5.5. Identification of Donor Cells after Transplantation. The availability of donor models providing cells with visual markers was critical for original development of GCT technique in mice $[1,2]$, because they allowed monitoring of the long-term fate of donor cells. Similar donor models are not readily available for use in farm animal GCT. Therefore, to track donor cells, researchers largely rely on fluorescence labeling of donors cells (although only traceable for a short period of time) $[32,39,43]$ or use genetic identification of donor-derived cells/sperm. As a proof-ofprinciple study, we transplanted testis cells from transgenic donor goats into testes of wild-type recipient goats, resulting in production of donor-derived sperm and subsequently transgenic progeny [34]. Microsatellite detection has also been used to identify donor-derived sperm DNA in the semen of recipient rams [44]. Alternatively, transplantation of normal testis cells into recipients with genetic aberrations such as the immotile short-tail sperm syndrome has been 
used to facilitate detection of normal pig sperm in the semen of recipient pigs as indication of GCT success [37].

5.6. Insertion of Genes into Donor Germ Cells. All adult stem cells have the ability to self-renew and to produce differentiated cells; however, SSCs are unique because they produce a lifetime supply of sperm in adults with the potential to contribute genes to progeny. Therefore, if SSCs are incorporated with genes of interest prior to transplantation, their resultant sperm will carry the transgene in the recipient. The desired genes for example can include those of visual markers to facilitate GCT studies and to serve as a step toward generating transgenic farm animals through GCT. Methods of DNA delivery into cells include chemical, lipofection, electroporation, and viral vectors. Compared with nonviral methods, recombinant viral vectors generally have very high cell transfection efficiency rates, and some are able to integrate the transgene into the SSC genome for stable expression. However, construction of the desired viral vectors is more involved and their use requires a facility with a higher biosafety level. Nonviral alternatives, on the other hand, are relatively easy to use and pertain virtually no biosafety risk to the operator or the public but their efficiency rates are usually much lower.

The work in transgenesis of germ cells for farm animal GCT is at early stages. Electroporation of bovine testis tissue in vitro resulted in transfection of SSCs shown after xenografting into the back of immunodeficient mice [91]. Transfection of pig germ cells was also reported after injection of plasmids mixed with a lipofection reagent into busulfan treated testes; however, it was unclear from the report whether SSCs were indeed transfected [92].

In a preliminary study, we used a recombinant adenoassociated virus (rAAV) containing the GFP reporter gene and CMV promoter to transfect isolated pig testis cells in vitro and observed GFP expression in cultured cells and in spermatogenic colonies for several months after GCT into recipient testes [93]. Subsequent use of rAAV vectors carrying the GFP for transfection of goat testis cells prior to GCT into recipient goats led to long-term expression of GFP in recipient testes and presence of transgenic sperm in $35 \%$ of the ejaculates. When semen from these recipient goats was used for in vitro fertilization, $10 \%$ of embryos were transgenic, showing germline transmission [27]. These results indicate that transgenesis via GCT in farm animals is a promising approach to generate transgenic animals.

\section{Potential Applications of Male Germ Cell Transplantation in Farm Animals}

Although technically still at an experimental level, there are significant potential applications for GCT in farm animals. This includes genetic modification of farm animals through transplantation of genetically altered male germ cells for improving productivity traits or producing transgenic farm animals. As such, GCT would be an alternative strategy to the currently inefficient and costly methods of generating transgenic farm animals [94, 95]. The development of transgenic pigs, for instance, is of interest because of its potential to provide tissues and organs for xenotransplantation to humans and as a model for biomedical research [96]. Genetically altered dairy goats, sheep, and cows are also of significant economic value for the production of biopharmaceutical proteins in their milk $[95,96]$. It has also been proposed that GCT can be used as an alternative way to artificial insemination for dissemination of elite sire bull genetics in extensive beef cattle grazing systems where animal handling is a limiting factor $[35,97]$. Another important potential application of GCT is to restore fertility by cryopreservation followed by transplantation of genetic material from immature males (as shown for testis tissue grafting [86]) of rare or valuable livestock breeds that die while they are premature or from horses that undergo early castration but display superior traits later in life. The advantage of using SSCs for genetic dissemination or fertility restoration is that SSCs can be harvested, cultured, propagated, cryopreserved, or transfected and still preserve the potential to colonize the recipient testes $[1,27,28,32$, $34,98-102]$. Since SSCs can both self-renew and produce a lifetime supply of sperm in adults, they have tremendous potential in modifying the male germ line as compared with, for example, the use of a finite amount of frozen semen from a given donor.

\section{Production of Live Progeny after Male Germ Cell Transplantation}

The birth of offspring carrying the donor haplotype after mating of a recipient can be viewed as the most convincing evidence for any successful GCT. In the initial report of GCT in mice, some of the infertile recipients produced enough donor-derived sperm to allow them to sire progeny [1]. As summarized in Table 1, among nonrodent species, live progeny has so far been produced following GCT in only goats and sheep, with an efficiency of $\sim 7-10 \%$ [34, 40]. The field application of this new technology for farm animals relies upon the efficient production of donor-derived offspring in the end. Therefore, the feasibility and efficiency of live offspring production via GCT in farm animals need to be investigated further and improved (Figure 1).

\section{Conclusions and Future Directions}

In a short period of time since the first reports in 20022003 [32-34, 36, 42], GCT in farm animals has shown great potential and promising initial results. Currently the percentage of donor-derived sperm in the semen of recipients after GCT is rather low, but evidence indicates that the efficiency can be improved. As we move beyond the stage of proof-of-principle studies, it is expected that the research in this area will focus more on improving a number of factors related to the success rate of the technique and on making it a viable option for downstream applications. These improvements are especially needed for obtaining higher numbers and purity of SSCs in the donor populations of cells. Another area of high potential is work on increasing the 
efficiency of nonviral transfection of germ cells, particularly if the ultimate transgenic animals are to be considered for generating products for human consumption. There are several advantages in pursuing farm animal transgenesis through GCT. For instance, the time from GCT into prepubertal recipient farm animals to first detection of transgenic sperm in the ejaculate is only a few months. Therefore, the time required to start collecting transgenic sperm may be reduced by one generation to about one half of that required by current methods. This time saving factor alone can significantly reduce the maintenance cost and accelerate the generation of a transgenic herd needed for large-scale production.

\section{Acknowledgments}

The authors thank the University of Saskatchewan Colleges of Graduate Studies and Veterinary Medicine for scholarships (to Y. Yang), and the Natural Sciences and Engineering Research Council (NSERC) of Canada for grants (to A. Honaramooz) to support the recent work from the current laboratory summarized in this paper.

\section{References}

[1] R. L. Brinster and M. R. Avarbock, "Germline transmission of donor haplotype following spermatogonial transplantation," Proceedings of the National Academy of Sciences of the United States of America, vol. 91, no. 24, pp. 11303-11307, 1994.

[2] R. L. Brinster and J. W. Zimmermann, "Spermatogenesis following male germ-cell transplantation," Proceedings of the National Academy of Sciences of the United States of America, vol. 91, no. 24, pp. 11298-11302, 1994.

[3] M. Nagano, M. R. Avarbock, and R. L. Brinster, "Pattern and kinetics of mouse donor spermatogonial stem cell colonization in recipient testes," Biology of Reproduction, vol. 60, no. 6, pp. 1429-1436, 1999.

[4] H. Ohta, K. Yomogida, S. Yamada, M. Okabe, and Y. Nishimune, "Real-time observation of transplanted 'green germ cells': proliferation and differentiation of stem cells," Development Growth and Differentiation, vol. 42, no. 2, pp. 105-112, 2000.

[5] F.-X. Jiang and R. V. Short, "Male germ cell transplantation in rats: apparent synchronization of spermatogenesis between host and donor seminiferous epithelia," International Journal of Andrology, vol. 18, no. 6, pp. 326-330, 1995.

[6] T. Ogawa, I. Dobrinski, and R. L. Brinster, "Recipient preparation is critical for spermatogonial transplantation in the rat," Tissue and Cell, vol. 31, no. 5, pp. 461-472, 1999.

[7] R. L. Brinster, "Germline stem cell transplantation and transgenesis," Science, vol. 296, no. 5576, pp. 2174-2176, 2002.

[8] R. L. Brinster, "Male germline stem cells: from mice to men," Science, vol. 316, no. 5823, pp. 404-405, 2007.

[9] D. E. Clouthier, M. R. Avarbock, S. D. Maika, R. E. Hammer, and R. L. Brinster, "Rat spermatogenesis in mouse testis," Nature, vol. 381, no. 6581, pp. 418-421, 1996.

[10] T. Ogawa, I. Dobrinski, M. R. Avarbock, and R. L. Brinster, "Xenogeneic spermatogenesis following transplantation of hamster germ cells to mouse testes," Biology of Reproduction, vol. 60, no. 2, pp. 515-521, 1999.
[11] I. Dobrinski, M. R. Avarbock, and R. L. Brinster, "Transplantation of germ cells from rabbits and dogs into mouse testes," Biology of Reproduction, vol. 61, no. 5, pp. 1331-1339, 1999.

[12] Y. Kim, V. Selvaraj, I. Dobrinski, H. Lee, M. C. Mcentee, and A. J. Travis, "Recipient preparation and mixed germ cell isolation for spermatogonial stem cell transplantation in domestic cats," Journal of Andrology, vol. 27, no. 2, pp. 248256, 2006.

[13] I. Dobrinski, M. R. Avarbock, and R. L. Brinster, "Germ cell transplantation from large domestic animals into mouse testes," Molecular Reproduction and Development, vol. 57, no. 3, pp. 270-279, 2000.

[14] M. Nagano, J. R. McCarrey, and R. L. Brinster, "Primate spermatogonial stem cells colonize mouse testes," Biology of Reproduction, vol. 64, no. 5, pp. 1409-1416, 2001.

[15] M. Nagano, P. Patrizio, and R. L. Brinster, "Long-term survival of human spermatogonial stem cells in mouse testes," Fertility and Sterility, vol. 78, no. 6, pp. 1225-1233, 2002.

[16] T. Shinohara, K. E. Orwig, M. R. Avarbock, and R. L. Brinster, "Restoration of spermatogenesis in infertile mice by Sertoli cell transplantation," Biology of Reproduction, vol. 68, no. 3, pp. 1064-1071, 2003.

[17] I. Dobrinski, T. Ogawa, M. R. Avarbock, and R. L. Brinster, "Computer assisted image analysis to assess colonization of recipient seminiferous tubules by spermatogonial stem cells from transgenic donor mice," Molecular Reproduction and Development, vol. 53, no. 2, pp. 142-148, 1999.

[18] A. Honaramooz, A. Snedaker, M. Boiani, H. Schöler, I. Dobrinski, and S. Schlatt, "Sperm from neonatal mammalia testes grafted in mice," Nature, vol. 418, no. 6899, pp. 778781, 2002.

[19] A. Honaramooz, M.-W. Li, M. C. T. Penedo, S. Meyers, and I. Dobrinski, "Accelerated maturation of primate testis by xenografting into mice," Biology of Reproduction, vol. 70, no. 5, pp. 1500-1503, 2004.

[20] S. Schlatt, S. S. Kim, and R. Gosden, "Spermatogenesis and steroidogenesis in mouse, hamster and monkey testicular tissue after cryopreservation and heterotopic grafting to castrated hosts," Reproduction, vol. 124, no. 3, pp. 339-346, 2002.

[21] J. M. Oatley, J. J. Reeves, and D. J. McLean, "Establishment of spermatogenesis in neonatal bovine testicular tissue following ectopic xenografting varies with donor age," Biology of Reproduction, vol. 72, no. 2, pp. 358-364, 2005.

[22] R. Rathi, A. Honaramooz, W. Zeng, R. Turner, and I. Dobrinski, "Germ cell development in equine testis tissue xenografted into mice," Reproduction, vol. 131, no. 6, pp. 1091-1098, 2006.

[23] R. Rathi, W. Zeng, S. Megee, A. Conley, S. Meyers, and I. Dobrinski, "Maturation of testicular tissue from infant monkeys after xenografting into mice," Endocrinology, vol. 149, no. 10, pp. 5288-5296, 2008.

[24] L. Arregui, R. Rathi, S. O. Megee et al., "Xenografting of sheep testis tissue and isolated cells as a model for preservation of genetic material from endangered ungulates," Reproduction, vol. 136, no. 1, pp. 85-93, 2008.

[25] J. Ehmcke and S. Schlatt, "Animal models for fertility preservation in the male," Reproduction, vol. 136, no. 6, pp. 717-723, 2008.

[26] M. Nakai, H. Kaneko, T. Somfai et al., "Production of viable piglets for the first time using sperm derived from ectopic testicular xenografts," Reproduction, vol. 139, no. 2, pp. 331$335,2010$. 
[27] A. Honaramooz, S. Megee, W. Zeng et al., "Adeno-associated virus (AAV)-mediated transduction of male germ line stem cells results in transgene transmission after germ cell transplantation," FASEB Journal, vol. 22, no. 2, pp. 374-382, 2008.

[28] M. Nagano, C. J. Brinster, K. E. Orwig, B.-Y. Ryu, M. R. Avarbock, and R. L. Brinster, "Transgenic mice produced by retroviral transduction of male germ-line stem cells," Proceedings of the National Academy of Sciences of the United States of America, vol. 98, no. 23, pp. 13090-13095, 2001.

[29] F. K. Hamra, J. Gatlin, K. M. Chapman et al., "Production of transgenic rats by lentiviral transduction of male germ-line stem cells," Proceedings of the National Academy of Sciences of the United States of America, vol. 99, no. 23, pp. 14931-14936, 2002.

[30] B.-Y. Ryu, K. E. Orwig, J. M. Oatley et al., "Efficient generation of transgenic rats through the male germline using lentiviral transduction and transplantation of spermatogonial stem cells," Journal of Andrology, vol. 28, no. 2, pp. 353-360, 2007.

[31] L. R. França, T. Ogawa, M. R. Avarbock, R. L. Brinster, and L. D. Russell, "Germ cell genotype controls cell cycle during spermatogenesis in the rat," Biology of Reproduction, vol. 59, no. 6, pp. 1371-1377, 1998.

[32] A. Honaramooz, S. O. Megee, and I. Dobrinski, "Germ cell transplantation in pigs," Biology of Reproduction, vol. 66, no. 1, pp. 21-28, 2002.

[33] A. Honaramooz, E. Behboodi, S. Blash, S. O. Megee, and I. Dobrinski, "Germ cell transplantation in goats," Molecular Reproduction and Development, vol. 64, no. 4, pp. 422-428, 2003.

[34] A. Honaramooz, E. Behboodi, S. O. Megee et al., "Fertility and germline transmission of donor haplotype following germ cell transplantation in immunocompetent goats," Biology of Reproduction, vol. 69, no. 4, pp. 1260-1264, 2003.

[35] M. Herrid, S. Vignarajan, R. Davey, I. Dobrinski, and J. R. Hill, "Successful transplantation of bovine testicular cells to heterologous recipients," Reproduction, vol. 132, no. 4, pp. 617-624, 2006.

[36] F. Izadyar, K. den Ouden, T. A. E. Stout et al., "Autologous and homologous transplantation of bovine spermatogonial stem cells," Reproduction, vol. 126, no. 6, pp. 765-774, 2003.

[37] M. Mikkola, A. Sironen, C. Kopp et al., "Transplantation of normal boar testicular cells resulted in complete focal spermatogenesis in a boar affected by the immotile short-tail sperm defect," Reproduction in Domestic Animals, vol. 41, no. 2, pp. 124-128, 2006.

[38] Y. Kim, D. Turner, J. Nelson, I. Dobrinski, M. McEntee, and A. J. Travis, "Production of donor-derived sperm after spermatogonial stem cell transplantation in the dog," Reproduction, vol. 136, no. 6, pp. 823-831, 2008.

[39] J. R. Rodriguez-Sosa, J. D. Silvertown, R. A. Foster, J. A. Medin, and A. Hahnel, "Transduction and transplantation of spermatogonia into the testis of ram lambs through the extra-testicular rete," Reproduction in Domestic Animals, vol. 44, no. 4, pp. 612-620, 2009.

[40] M. Herrid, J. Olejnik, M. Jackson et al., "Irradiation enhances the efficiency of testicular germ cell transplantation in sheep," Biology of Reproduction, vol. 81, no. 5, pp. 898-905, 2009.

[41] S. Schlatt, G. Rosiepen, G. F. Weinbauer, C. Rolf, P. F. Brook, and E. Nieschlag, "Germ cell transfer into rat, bovine, monkey and human testes," Human Reproduction, vol. 14, no. 1, pp. 144-150, 1999.
[42] H. Joerg, F. Janett, S. Schlatt et al., "Germ cell transplantation in an azoospermic Klinefelter bull," Biology of Reproduction, vol. 69, no. 6, pp. 1940-1944, 2003.

[43] J. R. Rodriguez-Sosa, H. Dobson, and A. Hahnel, "Isolation and transplantation of spermatogonia in sheep," Theriogenology, vol. 66, no. 9, pp. 2091-2103, 2006.

[44] S. Stockwell, M. Herrid, R. Davey, A. Brownlee, K. Hutton, and J. R. Hill, "Microsatellite detection of donor-derived sperm DNA following germ cell transplantation in cattle," Reproduction, Fertility and Development, vol. 21, no. 3, pp. 462-468, 2009.

[45] Z. Zhang, M. B. Renfree, and R. V. Short, "Successful intraand interspecific male germ cell transplantation in the rat," Biology of Reproduction, vol. 68, no. 3, pp. 961-967, 2003.

[46] M. Kanatsu-Shinohara, N. Ogonuki, K. Inoue et al., "Allogeneic offspring produced by male germ line stem cell transplantation into infertile mouse testis," Biology of Reproduction, vol. 68, no. 1, pp. 167-173, 2003.

[47] T. Shinohara, K. E. Orwig, M. R. Avarbock, and R. L. Brinster, "Germ line stem cell competition in postnatal mouse testes," Biology of Reproduction, vol. 66, no. 5, pp. 1491-1497, 2002.

[48] A. Honaramooz, E. Behboodi, C. L. Hausler et al., "Depletion of endogenous germ cells in male pigs and goats in preparation for germ cell transplantation," Journal of Andrology, vol. 26, no. 6, pp. 698-705, 2005.

[49] J. M. Oatley, A. Tibary, D. M. De Avila, J. E. Wheaton, D. J. McLean, and J. J. Reeves, "Changes in spermatogenesis and endocrine function in the ram testis due to irradiation and active immunization against luteinizing hormone-releasing hormone," Journal of Animal Science, vol. 83, no. 3, pp. 604612, 2005.

[50] T. Shinohara, K. E. Orwig, M. R. Avarbock, and R. L. Brinster, "Remodeling of the postnatal mouse testis is accompanied by dramatic changes in stem cell number and niche accessibility," Proceedings of the National Academy of Sciences of the United States of America, vol. 98, no. 11, pp. 6186-6191, 2001.

[51] T. Shinohara, K. E. Orwig, M. R. Avarbock, and R. L. Brinster, "Spermatogonial stem cell enrichment by multiparameter selection of mouse testis cells," Proceedings of the National Academy of Sciences of the United States of America, vol. 97, no. 15, pp. 8346-8351, 2000.

[52] T. Shinohara, M. R. Avarbock, and R. L. Brinster, " $\beta 1$ - and $\alpha 6$-integrin are surface markers on mouse spermatogonial stem cells," Proceedings of the National Academy of Sciences of the United States of America, vol. 96, no. 10, pp. 5504-5509, 1999.

[53] F.-X. Jiang, "Male germ cell transplantation: promise and problems," Reproduction, Fertility and Development, vol. 13, no. 7-8, pp. 609-614, 2001.

[54] M. Kanatsu-Shinohara, N. Ogonuki, T. Iwano et al., "Genetic and epigenetic properties of mouse male germline stem cells during long-term culture," Development, vol. 132, no. 18, pp. 4155-4163, 2005.

[55] R. A. J. Tegelenbosch and D. G. de Rooij, "A quantitative study of spermatogonial multiplication and stem cell renewal in the C3H/101 F1 hybrid mouse," Mutation Research, vol. 290, no. 2, pp. 193-200, 1993.

[56] C. Huckins, "The spermatogonial stem cell population in adult rats. I. Their morphology, proliferation and maturation," Anatomical Record, vol. 169, no. 3, pp. 533-557, 1971.

[57] A. Buageaw, M. Sukhwani, A. Ben-Yehudah et al., "GDNF family receptor alpha1 phenotype of spermatogonial stem 
cells in immature mouse testes," Biology of Reproduction, vol. 73, no. 5, pp. 1011-1016, 2005.

[58] T. Shinohara and R. L. Brinster, "Enrichment and transplantation of spermatogonial stem cells," International Journal of Andrology, Supplement, vol. 23, no. 2, pp. 89-91, 2000.

[59] A. M. M. van Pelt, A. R. Morena, F. M. F. van Dissel-Emiliani et al., "Isolation of the synchronized A spermatogonia from adult vitamin A-deficient rat testes," Biology of Reproduction, vol. 55, no. 2, pp. 439-444, 1996.

[60] T. Ogawa, I. Dobrinski, M. R. Avarbock, and R. L. Brinster, "Transplantation of male germ line stem cells restores fertility in infertile mice," Nature Medicine, vol. 6, no. 1, pp. 29-34, 2000.

[61] A. M. M. Van Pelt, F. M. F. Van Dissel-Emiliani, I. C. Gaemers, M. J. M. van der Burg, H. J. Tanke, and D. G. De Rooij, "Characteristics of a spermatogonia and preleptotene spermatocytes in the vitamin A-deficient rat testis," Biology of Reproduction, vol. 53, no. 3, pp. 570-578, 1995.

[62] K. E. Orwig, B.-Y. Ryu, M. R. Avarbock, and R. L. Brinster, "Male germ-line stem cell potential is predicted by morphology of cells in neonatal rat testes," Proceedings of the National Academy of Sciences of the United States of America, vol. 99, no. 18, pp. 11706-11711, 2002.

[63] H. Li, V. Papadopoulos, B. Vidic, M. Dym, and M. Culty, "Regulation of rat testis gonocyte proliferation by plateletderived growth factor and estradiol: identification of signaling mechanisms involved," Endocrinology, vol. 138, no. 3, pp. 1289-1298, 1997.

[64] A. R. Bellve, J. C. Cavicchia, and C. F. Millette, "Spermatogenic cells of the prepuberal mouse. Isolation and morphological characterization," Journal of Cell Biology, vol. 74, no. 1, pp. 68-85, 1977.

[65] M. Herrid, R. J. Davey, K. Hutton, I. G. Colditz, and J. R. Hill, "A comparison of methods for preparing enriched populations of bovine spermatogonia," Reproduction, Fertility and Development, vol. 21, no. 3, pp. 393-399, 2009.

[66] D. G. de Rooij and A. M. M. van Pelt, "Spermatogonial Stem Cell Biology," Annual Review of Biomedical Sciences, vol. 5, pp. 105-114, 2003.

[67] J. Luo, S. Megee, R. Rathi, and I. Dobrinski, "Protein gene product 9.5 is a spermatogonia-specific marker in the pig testis: application to enrichment and culture of porcine spermatogonia," Molecular Reproduction and Development, vol. 73, no. 12, pp. 1531-1540, 2006.

[68] K. C. Lo, V. M. Brugh III, M. Parker, and D. J. Lamb, "Isolation and enrichment of murine spermatogonial stem cells using rhodamine 123 mitochondrial dye," Biology of Reproduction, vol. 72, no. 3, pp. 767-771, 2005.

[69] F. M. F. van Dissel-Emiliani, D. G. De Rooij, and M. L. Meistrich, "Isolation of rat gonocytes by velocity sedimentation at unit gravity," Journal of Reproduction and Fertility, vol. 86, no. 2, pp. 759-766, 1989.

[70] J. M. Orth, J. Qiu, W. F. Jester Jr., and S. Pilder, "Expression of the c-kit gene is critical for migration of neonatal rat gonocytes in vitro," Biology of Reproduction, vol. 57, no. 3, pp. 676-683, 1997.

[71] Y. Yang, M. Yarahmadi, and A. Honaramooz, "Development of novel strategies for the isolation of piglet testis cells with a high proportion of gonocytes," Reproduction, Fertility and Development, vol. 22, no. 7, pp. 1057-1065, 2010.

[72] H. Khaira, D. McLean, D. A. Ohl, and G. D. Smith, "Spermatogonial stem cell isolation, storage, and transplantation," Journal of Andrology, vol. 26, no. 4, pp. 442-450, 2005.
[73] N. R. Moudgal, M. R. Sairam, H. N. Krishnamurthy, S. Sridhar, H. Krishnamurthy, and H. Khan, "Immunization of male bonnet monkeys (M. radiata) with a recombinant FSH receptor preparation affects testicular function and fertility," Endocrinology, vol. 138, no. 7, pp. 3065-3068, 1997.

[74] F. Izadyar, G. T. Spierenberg, L. B. Creemers, K. den Ouden, and D. G. de Rooij, "Isolation and purification of type A spermatogonia from the bovine testis," Reproduction, vol. 124, no. 1, pp. 85-94, 2002.

[75] H. Kubota, M. R. Avarbock, and R. L. Brinster, "Culture conditions and single growth factors affect fate determination of mouse spermatogonial stem cells," Biology of Reproduction, vol. 71, no. 3, pp. 722-731, 2004.

[76] G. Giuili, A. Tomljenovic, N. Labrecque, M. OuladAbdelghani, M. Rassoulzadegan, and F. Cuzin, "Murine spermatogonial stem cells: targeted transgene expression and purification in an active state," EMBO Reports, vol. 3, no. 8, pp. 753-759, 2002.

[77] K. Gassei, J. Ehmcke, and S. Schlatt, "Efficient enrichment of undifferentiated GFR alpha 1+ spermatogonia from immature rat testis by magnetic activated cell sorting," Cell and tissue research, vol. 337, no. 1, pp. 177-183, 2009.

[78] V. von Schönfeldt, H. Krishnamurthy, L. Foppiani, and S. Schlatt, "Magnetic cell sorting is a fast and effective method of enriching viable spermatogonia from djungarian hamster, mouse, and marmoset monkey testes," Biology of Reproduction, vol. 61, no. 3, pp. 582-589, 1999.

[79] H. Kubota, M. R. Avarbock, and R. L. Brinster, "Spermatogonial stem cells share some, but not all, phenotypic and functional characteristics with other stem cells," Proceedings of the National Academy of Sciences of the United States of America, vol. 100, no. 11, pp. 6487-6492, 2003.

[80] C. Marret and P. Durand, "Culture of porcine spermatogonia: effects of purification of the germ cells, extracellular matrix and fetal calf serum on their survival and multiplication," Reproduction Nutrition Development, vol. 40, no. 3, pp. 305-319, 2000.

[81] G. Dirami, N. Ravindranath, V. Pursel, and M. Dym, "Effects of stem cell factor and granulocyte macrophagecolony stimulating factor on survival of porcine type a spermatogonia cultured in KSOM," Biology of Reproduction, vol. 61, no. 1, pp. 225-230, 1999.

[82] T. J. Moore, M. de Boer-Brouwer, and F. M. F. van DisselEmiliani, "Purified gonocytes from the neonatal rat form foci of proliferating germ cells in vitro," Endocrinology, vol. 143, no. 8, pp. 3171-3174, 2002.

[83] R. van den Ham, A. M. M. van Pelt, M. P. de Miguel, P. J. S. van Kooten, N. Walther, and F. M. F. van Dissel-Emilani, "Immunomagnetic isolation of fetal rat gonocytes," American Journal of Reproductive Immunology, vol. 38, no. 1, pp. 39-45, 1997.

[84] S. Goel, M. Sugimoto, N. Minami, M. Yamada, S. Kume, and H. Imai, "Identification, isolation, and in vitro culture of porcine gonocytes," Biology of Reproduction, vol. 77, no. 1, pp. 127-137, 2007.

[85] F. Izadyar, J. J. Matthijs-Rijsenbilt, K. Den Ouden, L. B. Creemers, H. Woelders, and D. G. De Rooij, "Development of a cryopreservation protocol for type A spermatogonia," Journal of Andrology, vol. 23, no. 4, pp. 537-545, 2002.

[86] M. Abrishami, M. Anzar, Y. Yang, and A. Honaramooz, "Cryopreservation of immature porcine testis tissue to maintain its developmental potential after xenografting into recipient mice," Theriogenology, vol. 73, no. 1, pp. 86-96, 2010. 
[87] W. Zeng, A. K. Snedaker, S. Megee et al., "Preservation and transplantation of porcine testis tissue," Reproduction, Fertility and Development, vol. 21, no. 3, pp. 489-497, 2009.

[88] K. Jahnukainen, J. Ehmcke, S. D. Hergenrother, and S. Schlatt, "Effect of cold storage and cryopreservation of immature non-human primate testicular tissue on spermatogonial stem cell potential in xenografts," Human Reproduction, vol. 22, no. 4, pp. 1060-1067, 2007.

[89] Y. Yang, J. Steeg, and A. Honaramooz, "The effects of tissue sample size and media on short-term hypothermic preservation of porcine testis tissue," Cell and Tissue Research, vol. 340, no. 2, pp. 397-406, 2010.

[90] Y. Yang and A. Honaramooz, "Effects of medium and hypothermic temperatures on preservation of isolated porcine testis cells," Reproduction, Fertility and Development, vol. 22, no. 3, pp. 523-532, 2010.

[91] J. M. Oatley, D. M. de Avila, J. J. Reeves, and D. J. McLean, "Spermatogenesis and germ cell transgene expression in xenografted bovine testicular tissue," Biology of Reproduction, vol. 71, no. 2, pp. 494-501, 2004.

[92] J.-H. Kim, H.-S. Jung-Ha, H.-T. Lee, and K.-S. Chung, "Development of a positive method for male stem cellmediated gene transfer in mouse and pig," Molecular Reproduction and Development, vol. 46, no. 4, pp. 515-526, 1997.

[93] A. Honaramooz et al., "Use of adeno-associated virus for transfection of male germ cells for transplantation in pigs," Theriogenology, vol. 1, no. 59, p. 536, 2003.

[94] H. Niemann and W. A. Kues, "Transgenic farm animals: an update," Reproduction, Fertility and Development, vol. 19, no. 6, pp. 762-770, 2007.

[95] C. L. Keefer, "Production of bioproducts through the use of transgenic animal models," Animal Reproduction Science, vol. 82-83, pp. 5-12, 2004.

[96] H. Niemann and W. A. Kues, "Application of transgenesis in livestock for agriculture and biomedicine," Animal Reproduction Science, vol. 79, no. 3-4, pp. 291-317, 2003.

[97] J. R. Hill and I. Dobrinski, "Male germ cell transplantation in livestock," Reproduction, Fertility and Development, vol. 18, no. 1-2, pp. 13-18, 2006.

[98] M. R. Avarbock, C. J. Brinster, and R. L. Brinster, "Reconstitution of spermatogenesis from frozen spermatogonial stem cells," Nature Medicine, vol. 2, no. 6, pp. 693-696, 1996.

[99] M. Nagano, M. R. Avarbock, E. B. Leonida, C. J. Brinster, and R. L. Brinster, "Culture of mouse spermatogonial stem cells," Tissue and Cell, vol. 30, no. 4, pp. 389-397, 1998.

[100] M. Nagano, T. Shinohara, M. R. Avarbock, and R. L. Brinster, "Retrovirus-mediated gene delivery into male germ line stem cells," FEBS Letters, vol. 475, no. 1, pp. 7-10, 2000.

[101] T. Shinohara, M. Kato, M. Takehashi et al., "Rats produced by interspecies spermatogonial transplantation in mice and in vitro microinsemination," Proceedings of the National Academy of Sciences of the United States of America, vol. 103, no. 37, pp. 13624-13628, 2006.

[102] E. Goossens, V. Frederickx, G. De Block, A. C. Van Steirteghem, and H. Tournaye, "Reproductive capacity of sperm obtained after germ cell transplantation in a mouse model," Human Reproduction, vol. 18, no. 9, pp. 1874-1880, 2003. 

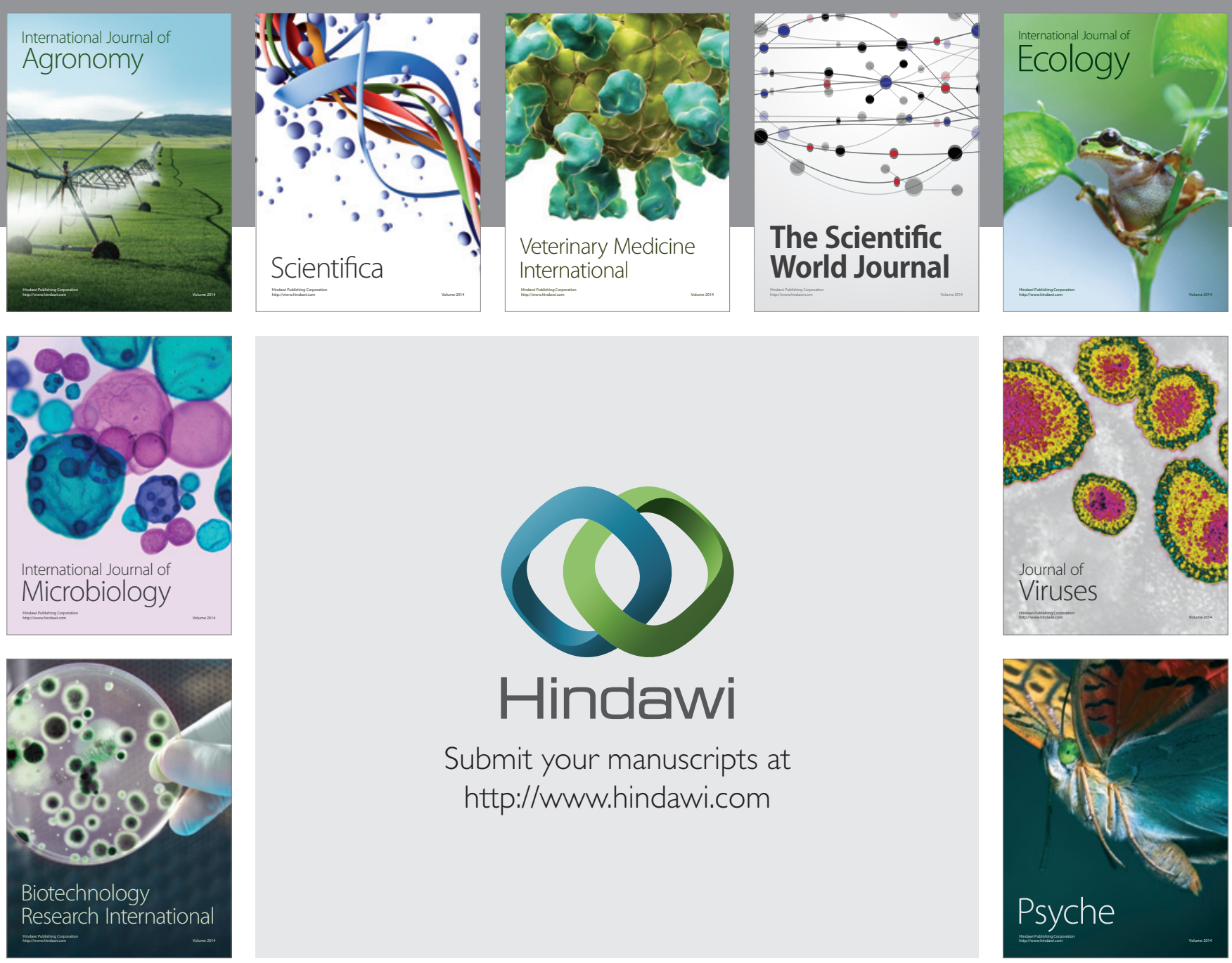

Submit your manuscripts at

http://www.hindawi.com
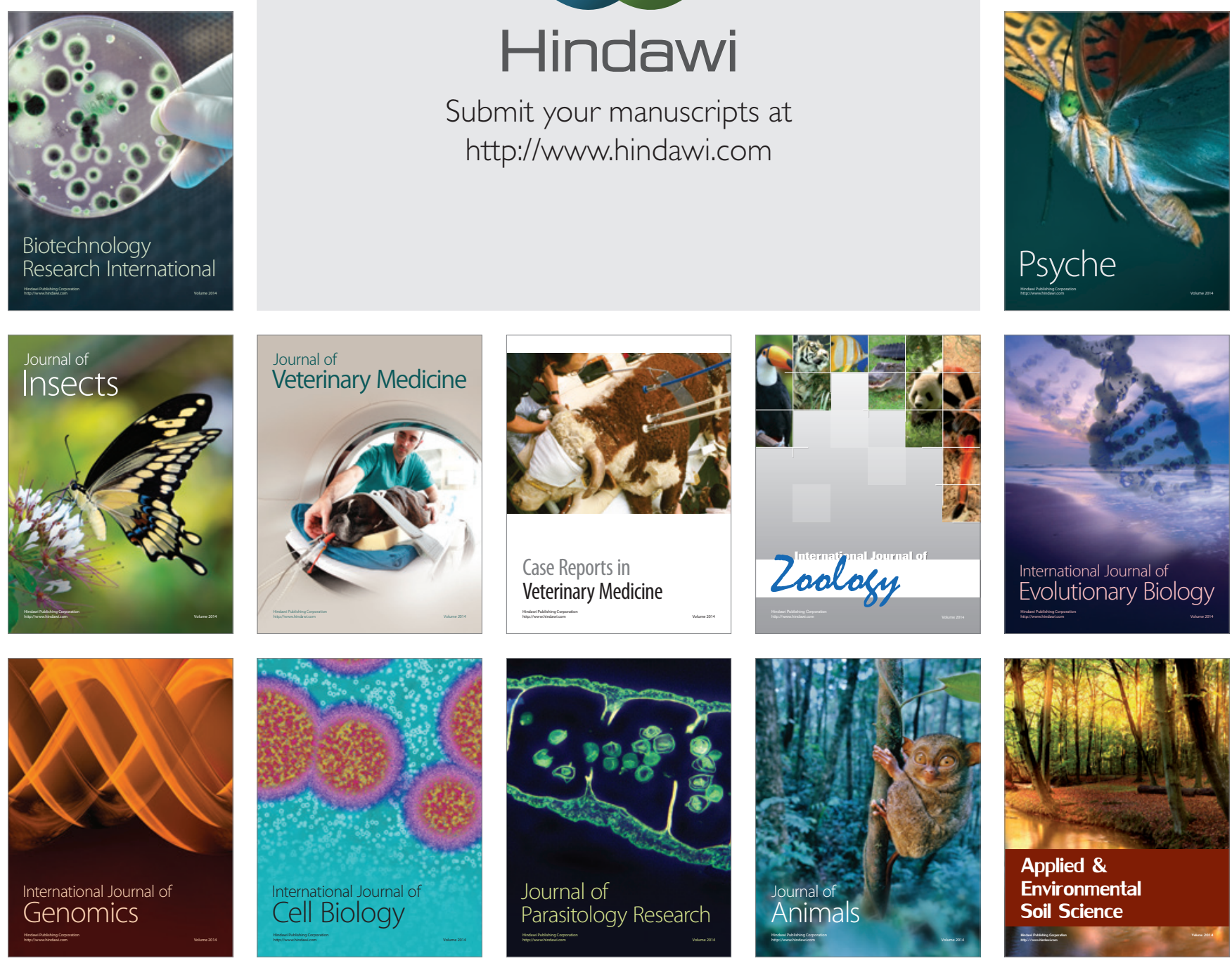